http://ojs.umb-bungo.ac.id/index.php/RIO

Vol 1, No 1 Februari 2020

\title{
ANALISIS YURIDIS PEMBALIKAN BEBAN PEMBUKTIAN PADA TINDAK PIDANA KORUPSI
}

\author{
Khaidir \\ Dosen Universitas Muara Bungo \\ Email : Khas_Saleh@Yahoo.com
}

\section{RINGKASAN}

Yang melandasi dasar kebijakan perumusan pembalikan beban pembuktian dalam peraturan tindak pidana korupsi di Indonesia diatur dalam ketentuan Pasal 12B, Pasal 37, Pasal 37 A, dan Pasal 38B UU Nomor 31 Tahun 1999 Jo UU Nomor 20 tahun 2001 terdapat ketidakjelasan dan ketidakharmonisan perumusan norma pembalikan beban pembuktian ketentuan Pasal 12B dari Perspektif perumusan unsur delik dicantumkan secara lengkap dan jelas (Materiele Feit) dalam suatu pasal sehingga membawa implikasi yuridis, jaksa penuntut umum imperative membuktikan perumusan delik tersebut, karena seluruh bagian inti delik tersebut sehingga yang tersisa untuk dibuktikan sebaliknya malah tidak ada. Kemudian ketentuan Pasal 37 senyatanya bukanlah pembalikan beban pembuktian karena dicantumkan atau tidak norma Pasal tersebut tidak akan berpengaruh bagi terdakwa untuk melakukan pembelaan terhadap dakwaan.

Ketentuan pasal 38B hanya ditujukan terhadap pembalikan beban pembuktian untuk harta banda yang belum didakwakan dan hanya dapat dijatuhkan terhadap tindak pidana pokok (Pasal 37A ayat (3)) dan tidak dapat dijatuhklan terhadap gratifikasi sesuai ketentuan Pasal 12B ayat (1) Huruf (a) UU nomor 31 Tahun 1999 Jo UU Nomor 20 Tahun 2001. Oleh karena itu, khusus terhadap gratifikasi jaksa penuntut umum tidak dapat melakukan perampasan harta pelaku yang diduga melakukan tindak pidana korupsi, begitupun sebaliknya terdakwa tidak dapat dibebankan melakukan pembalikan beban pembuktian terhadap asal usul hartanya. Pasca berlakuknya Konvensi Perserikatan Bangsa-Bangsa Anti Korupsi 2003 (KAK 2003) diperlukan suatu modifikasi perumusan norma pembalikan beban pembuktian yang bersifat preventif, represif, dan restorative.

Penerapan ketentuan pembalikan beban pembuktian berdasarkan UU Nomor 31 Tahun 1999 tentang Pemberantasan Tindak Pidana Korupsi, diubah UU Nomor 20 Tahun 2001 belum efektif karena belum diperkuat oleh hukum acara tersendiri sehingga dalam proses persidangan perkara korupsi hakim belum dapat menerapkan ketentuan tersebut. Didalam praktik proses pembalikan beban pembuktian dalam UU Nomor 31 tahun 1999 yang diubah UU Nomor 20 tahun 2001 belum dapat digunakan sebagai sarana hukum untuk mempercepat proses pemulihan kerugian/perekonomian Negara (Asset Recovery).

Faktor yang menghambat pembalikan beban pembuktian dalam tindak pidana korupsi adalah pembuktian terbalik bertentangan dengan asas praduga tidak bersalah karena tersangka atau terdakwa dianggap telah terbukti bersalah kecuali ia bisa membuktikan bahwa dirinya tidak bersalah. Menyangkut pelanggaran hak asasi manusia dalam kategori hak untuk diakui sebagai pribadi di dalam hukum, danhak untuk tidak dituntut atas dasar hukum yang berlaku surut, walaupun peraturan tentang pelaporan harta kekayaan pejabat sudah ada, apabila penerapan asas ini tidak 
secara profesional hal tersebut dapat timbul. Di tunjang dengan kurangnya bukti atau kurang kuatnya bukti yang ada maka akan dapat memudahkan terdakwa lepas dari jerat hukum. Disamping adanya kelemahan-kelemahan tersebut kekurangan efektifan dari sistem pembuktian terbalik ini juga di karenakan adanya kendala-kendala yang ada dalam sistem pembuktian terbalik tersebut, seringkali dimafaatkan terdakwa untuk menyatakan bahwa ia tidak bersalah melakukan korupsi, kurangnya ahli untuk mengusut kasus korupsi, masih banyaknya jumlah hakim dan jaksa yang tidak bersih, kurangnya peran serta masyarakat.

\title{
Kata kunci : Analisis Yuridis, Pembalikan Beban Pembuktian, Tindak Pidana Korupsi.
}

\begin{abstract}
ABSTRACK
Underlying the basic policy of the formulation of the reversal of the burden of proof in the regulation of criminal acts of corruption in Indonesia is regulated in the provisions of Article 12B, Article 37, Article 37 A, and Article 38B of Law Number 31 of 1999 Jo of Law Number 20 of 2001 there is a lack of clarity and disharmony in the formulation of norms of reversal of burden Proving the provisions of Article 12B of the Perspective on the formulation of the offense element is stated in a complete and clear manner (Materiele Feit) in an article so that it has juridical implications, the imperative public prosecutor proves the formulation of the offense, because all parts of the offense core so that what remains to be proven otherwise does not even exist. Then the provisions of Article 37 in fact are not a reversal of the burden of proof because they are included or not the norm of the Article will not affect the defendant to defend the indictment.

The provisions of article 38B are only aimed at reversing the burden of proof for assets which have not been charged and can only be imposed on a principal crime (Article 37A paragraph (3)) and cannot be subject to gratuity in accordance with Article 12B paragraph (1) Letter (a) of the Law number 31 of 1999 Jo Law Number 20 of 2001. Therefore, specifically for the gratuity of the public prosecutor can not seize the assets of the perpetrators suspected of committing corruption, and vice versa the defendant cannot be charged with reversing the burden of proof of the origin of his property. After the entry into force of the 2003 United Nations Anti-Corruption Convention (KAK 2003), a modification of the formulation of norms for reversing the burden of evidence which is preventive, repressive and restorative is needed.

The application of the reversal of the provisions of the burden of proof based on Law Number 31 of 1999 concerning Eradication of Corruption, amended by Law Number 20 of 2001 has not been effective because it has not been strengthened by a separate procedural law so that in the trial process of corruption the judge has not been able to apply the provision. In practice the process of reversing the burden of proof in Law Number 31 of 1999 amended by Law Number 20 of 2001 cannot be used as a legal tool to accelerate the process of recovery of losses / the State's economy (Asset Recovery).
\end{abstract}


The factor that inhibits the reversal of the burden of proof in corruption is reversed proof contrary to the principle of presumption of innocence because the suspect or defendant is deemed to have been proven guilty unless he can prove himself innocent. Concerning human rights violations in the category of rights to be recognized as individuals in law, and the right not to be prosecuted on the basis of a retroactive law, even though regulations on reporting official assets are already in place, if the application of this principle is not professionally the case may arise. Supported by the lack of evidence or lack of evidence, it will be easier for the defendant to escape the legal trap. Besides these weaknesses, the lack of effectiveness of the reverse verification system is also due to the constraints that exist in the reverse proof system, often the defendant uses the defendant to state that he is innocent of corruption, lack of expertise to investigate corruption cases, there are still many unclean judges and prosecutors, lack of community participation.

\section{Keywords: Juridical Analysis, Proof Burden Reversal, Corruption Crime.}

\section{LATAR BELAKANG}

Terbentuknya negara Indonesia tidak lain memiliki suatu tujuan yang mulia yaitu mendorong dan menciptakan kesejahteraan umum dalam payung Negara Kesatuan Republik Indonesia yang berdasarkan Pancasila. Tujuan atau cita-cita tersebut tercermin dalam pembukaan UndangUndang Dasar Negara Republik Indonesia Tahun 1945 dalam alinea ke4 (empat) yaitu : Kemudian daripada itu untuk membentuk suatu Pemerintahan Negara Indonesia yang melindungi segenap banga Indonesia dan seluruh tumpah darah Indonesia dan untuk memajukan kesejateraan umum, mencerdaskan kehidupan bangsa dan ikut melaksanakan ketertiban dunia yang berdasarkan kemerdekaan, perdamaian abadi dan keadilan sosial,

Kesejahteraan bagi seluruh rakyat Indonesia hanya sekedar cita-cita belaka jika tanpa diiringi oleh usaha yang nyata oleh penyelenggara Negara dalam mengemban amanat konstitusi, slah satu upaya nyata adalah dengan merumuskan suatu perundang- undangan yang bertujuan melindungi segenap bangsa dan tumpah darah dari segala kesewenang-wenangan termasuk kesewenang-wenangan mengenai hakhak perekonomian rakyat.

Tindak pidana korupsi merupakan perbuatan yang bukan saja dapat merugikan keuangan negara akan tetapi juga dapat menimbulkan kerugian pada perekonomian rakyat. Barda Nawawi Arief berpendapat bahwa, tindak pidana korupsi merupakan perbuatan yang sangat tercela, terkutuk dan sangat dibenci oleh sebagian besar masyarakat, tidak hanya oleh masyarakat dan bangsa Indonesia tetapi oleh masyarakat bangsa-bangsa didunia

Oleh karena itu sudah semestinya, sebagai bangsa yang memiliki semangat untuk menciptakan kemakmuran secara merata dan adil mampu untuk mengenali dan oleh karena itu sudah semestinya, sebagai bangsa yang memiliki semangat untuk menciptakan kemakmuran secara merata dan adil mampu untuk mengenali dan menghindari setiap bentuk korupsi yang hanya akan dapat 
menciptakan kesengsaraan bagi segenap rakyat Indonesia. Dengan mengenali bentuk-bentuk korupsi juga diharapkan korupsi menjadi musuh bersama yang harus ditekan dan dihilangkan dari setiap permukaan bumi Indonesia.

Pengalaman empiris selama ini menunjukan, walaupun secara teoritis kendala tersebut dapat di atasi melalui instrument Pasal 37 dan 38 UndangUndang Nomor 20 Tahun 2001, namun hemat Peneliti kuantitas maupun kualitas tindak pidana korupsi belum menunjukan arah penurunan yang sinifikan. Permasalahan inilah yang hendak Peneliti kaji dan analisis, kaitan antara Pasal 37 tentang pembalikan beban pembuktian yang bersifat terbatas dan berimbang dalam upaya menanggulangi tindak pidana korupsi di Indonesia.

\section{METODE PENELITIAN}

Metode pengumpulan data yang digunakan dalam penelitian ini adalah melalui penelitian kepustakaan (libary research) untuk mendapatkan konsepsi, teori, atau doktrin, pendapat atau pemikiran konseptual dari peneliti pendahulu yang berhubungan dengan objek telaahan penelitian ini yang dapat berupa peraturan perundang-undangan dan karya ilmiah lainnya.

Dari sudut informasi, maka penelitian kepustakaan dapat dibagi atas tiga kelompok, yaitu:

a. Bahan hukum primer, yaitu UU Nomor 31 Tahun 1999 Jo UU Nomor 20 Tahun 2001 Tentang Pemberantasan Tindak Pidana Korupsi, UU Nomor 30 Tahun 2002 Tentang Komisi Pemberantasan Korupsi, UU Nomor 28 Tahun 1999 Tentang Penyelenggaraan Negara yang bebas dari Kolusi, Korupsi, dan Nepotisme.

b. Bahan hukun sekunder, yaitu bahan yang memberikan penjelasan mengenai bahan hukum primer, seperti hasil-hasil seminar atau pertemuan ilmiah lainnya, bahkan dokumen pribadi atau pendapat kalangan pakar hukum sepanjang relavan dengan objek penelitian ini.

c. Bahan hukum tertier, yaitu bahan hukum penunjang yang memberikan petunjuk dan penjelasan terhadap bahan hukum primer dan bahan hukum sekunder, seperti kamus, majalah dan jurnal ilmiah.

Dalam analisis data akan dilakukan penalahaan terhadap peraturan perundang-undangan yang mengatur tentang kebijakan hukum pidana (penal policy) dalam penanggulangan tindak pidana korupsi. Data yang berupa penelitian tersebut akan dianalisis secara dedukatif agar sampai pada suatu kesimpulan akhir yang akan menjawab semua pokok permasalahan dalam penelitian ini.

\section{HASIL DAN PEMBAHASAN.}

\section{Landasan Dasar Kebijakan Perumusan} Pembalikan Beban Pembuktian.

Sistem Hukum Pidana Indonesia meliputi hukum pidana materiil dan hukum pidana formal. Hukum pidana materiil terdapat dalam KUHP maupun di luar KUHP. Kemudian hukum pidana formal bersumber pada Undang-Undang nomor 8 Tahun 1981 tentang Kitab Undang-Undang Hukum Acara Pidana (KUHAP). Oleh karena itu, tindak pidana umum dalam KUHP maupun tndak pidana khusus di luar KUHP sebagaimana halnya tindak pidana korupsi mengenal hukum pembuktian.

Secara yuridi historis, pengaturan secara khusus mengenai pencegahan dan pembrantasan tindak pidana korupsi di Indonesia, dimulai dengan disyahkannya Undang-Undang Republik Nomor 3 Tahun 1971 tentang Pembrantasan Tindak Pidana Korupsi. 
Seiring dengan semangat reformasi, Undang-Undang Republik Nomor 3 Tahun 1971 tentang Pemberantasan Tindak Pidana Korupsi, dipandang belum mampu memenuhi dan mengantisipasi perkembangan kebutuhan hukum masyarakat dalam rangka mencegah dan memberantas secara lebih efektif setiap bentuk tindak pidana korupsi yang sangat merugikan keuangan negara atau perekonomian negara pada khususnya serta masyarakat pada umumnya.

Pada tanggal 16 Agustus 1999 diundangkan Undang-Undang Republik Indonesia Nomor 13 Tahun 1999 tentang Pemberantasan Tindak Pidana Korupsi. Adapun latar belakang yang mendasari lahirnya Undang-Undang yang ditempatkan pada Lembaran Negara Republik Indonesia Tahun 1999 Nomor 140 tersebut, antara lain adalah bahwa tindak pidana korupsi sangat merugikan keuangan negara atau perekonomian negara dan menghambat pembangunan nasional, sehingga harus diberantas dalam rangka mewujudkan masyarakat adil dan makmur berdasarkan Pancasila dan Undang-Undang Dasar 1945.

\section{Penerapan Pembalikan Beban Pembuktian Dalam Pemberatasan Tindak Pidana Korupsi.}

Pembuktian terbalik sebenarnya bukanlah hal yang baru di negeri ini. Undang-Undang Nomor 23 Tahun 1997 tentang Pengelolaan Lingkungan Hidup maupun UU Nomor 8 Tahun 1999 tentang Perlindungan Konsumen, secara tegas mengatur penerapan asas pembuktian terbalik itu walaupun berbeda alasan yang mendasarinya dan penerapannya pada persidangan.

Misalnya penerapan asas

pembuktian terbalik dalam UU Nomor 8
Tahun 1999, adalah sebab konsumen tidak mengetahui bahan untuk proses produksi dan ketentuan distribusi yang dilakukan produsen. Konsumen perlu dilindungi, kalau dirugikan oleh produsen. Di Pengadilan produsen yang harus membuktikan bahwa bahan produksi dan proses distribusi yang dilakukannya tak merugikan konsumen. Kalau produsen bisa membuktikan dirinya tidak "mencurangi" konsumen, dia bisa terbebas dari tuntutan ganti rugi.

Pada hakikatnya, penerapan pembalikan beban pembuktian dalam perkara Tindak Pidana Korupsi di Indonesia yang diatur dalam ketentuan Pasal 12B, 37 dan 37A, 38B UU Nomor 31 Tahun 1999 jo UU Nomor 20 Tahun 2001 tentang Pemberantasan Tindak Pidana Korupsi, menimbulkan problematika, yaitu : Pertama, ketentuan Pasal 37 UU Nomor UU Nomor 311999 jo UU Nomor 20 Tahun 2001 senyatanya bukanlah pembalikan beban pembuktian oleh karena ketentuan tersebut semata-mata adalah hak sehingga ada tidaknya pasal itu tidak akan berpengaruh terhadap pembuktian yang dilakukan terdakwa.

Walaupun norma pasal 37 tidak dicantumkan dalam UU Tndak Pidana Korupsi terdakwa tetap melakukan pembelaan diri terhadap dakwaan yang dituduhkan kepada dirinya.

Berikutnya, apabila ketentuan Pasal 37 dimaksudkan pembentuk undangundang sebagai pembalikan beban pembuktian maka hal ini berhubungan dengan kesalahan yang bertitik tolak asas praduga bersalah dan asas mempersalahkan diri sendiri. Padahal dalam tindak pidana korupsi pokok selain gratifikasi haruslah mempergunakan asas pradug tidak bersalah dan kewajiban membuktikan tetap dibebankan kepada jaksa penuntut umum. 
Kedua, pembalikan beban pembuktian terhadap harta benda terdakwa yang belum didakwaan (Pasal 38B) hanya dapat dijatuhkan terhadap pidana pokok (Pasal 37A ayat (3) dan tidak dapat dijatuhkan terhadap gratifikasi sesuai ketentuan Pasal 12B ayat (1) huruf a UU Nomor 31 Tahun 1999 jo UU Nomor 20 Tahun 2001. Lebih jauh dapat dikatakan bahwa khusus terhadap gratifikasi Pasal 12B ayat (1) huruf a UU Nomor 31 Tahun 1999 jo UU Nomor 20 Tahun 2001 maka jaksa penuntut umum tidak dapat melakukan perampasan harta pelaku yang diduga melakukan tindak pidana korupsi. Begitu juga sebaliknya terdakwa tidak dibebankan melakukan pembalikan beban pembuktian terhadap asal usul hartanya.

Ketiga, pasca berlakunya Konvensi Perserikatan Bangsa-Bangsa Anti Korupsi 2003 (KAK 2003) maka pembalikan bebab pembuktian ditujukan dalam konteks keperdataan (civilprocedure) untuk mengembalikan harta pelaku yang diakibatkan dari perbuatan korupsi. Adanya pengaturan pembalikan beban pembuktian dalam ketentuan Pasal 37 dengan delik gratifikasi Pasal 12B UU Nomor 31 Tahun 1999 jo UU Nomor 20 Tahun 2001 maka korelasinya pembalikan beban pembuktian pada ketentuan Pasal 37 berlaku pada tindak pidana suap menerima gratifikasi yang nilainya Rp. 10.000.000. (sepuluh juta rupiah) atau lebih (Pasal 12B ayat (1) huruf a). Kemudian korelasinya dengan Pasal 37A ayat (3) bahwa pembalikan beban pembuktian menurut ketentuan Pasal 37 berlaku dalam aspek pembuktian tentang sumber (asal) harta benda terdakwa dan lain-lain di luar perkara pokok sebagaimana pasal-pasal yang disebutkan dalam ketentuan Pasal 37A in casu hanya terhadap tindak pidana korupsi suap gratifikasi yang tidak disebut dalam ketentuan Pasal 37A ayat (3) UU Nomor 20 Tahun 2001.

Fakta di dalam masyarakat dan di pengadilan banyak putusan hakim terhadap pelaku tindak pidana korupsi akan tetapi sampai sekarang relatif belum ditemukan penerapan kasus pembalikan dan pembuktian. Oleh karena ada nuansa ditataran implementasi sehingga tentu menarik apabila dikaji lebih detail tentang bagaiman praktik peradilan pidana terhadap asas pembalikan beban pembuktian perkara tindak pidana korupsi jikalau dihubungkan dengan KAK 2003 dan bagaimana kebijakan legislasi terhadap pembalikan beban pembuktian dalam peraturan tindak pidana korupsi di Indonesia tersebut beserta implikasi tersebut baik terhadap praktik peradilan dan perumusan norma pada umumnya di satu sisi dan di sisi lainnya tentu diperlukan pula adanya suatu solusi bagaimana sebaiknya kebijakan legislasi memformulasikan pengaturan secara normatif mengenai asas pembalikan beban pembuktian dalam tindak pidana korupsi yang sulit pembuktiannya terutama menyangkut asal usul kekayaan pelaku dengan implikasi adanya KAK 2003 yang sesuai dengan sistem hukum pidana Indonesisa.

Undang Undang Nomor 20 Tahun 2001 mengatur penerapan pembuktian tebalik yang bersifat terbatas atau berimbang. Yakni terdakwa mempunyai hak untuk membuktikan bahwa apabila terdakwa tidak melakukan tindak pidana korupsi dan wajib memberikan keterangan tentang seluruh harta bendanya dan harta benda istri nya atau suaminya, anak, dan harta benda setiap orang atau korporasi yang diduga mempunyai hubungan dengan perkara yang bersangkutan dan penuntut umum 
tetap berkewajiban membuktikan dakwaannya (sesuai dengan Pasal 28 dan Pasal 37)

Sistem pembuktian terbalik (omkering van de bewijslast) merupakan cara yang jitu untuk "mematikan" pelaku korupsi. Dalam pembuktian terbalik, orang yang dituduh melakukan tindak pidana itulah yang harus membuktikan di depan pengadilan, bahwa ia tidak bersalah. Berbeda dengan pembuktian biasa, dimana jaksa yang harus membuktikan seseorang bersalah atau tidak dalam hal terjadi tindak pidana.

Faktor yang menjadi hambatan pembalikan beban pembuktian dalam pemberantasan tindak pidana korupsi

Dengan sistem pembuktian

terbalik ternyata masih kurang efektif untuk upaya penanggulangan korupsi sebab masih ada kelemahan didalamnya yaitu pembuktian terbalik juga bertentangan dengan asas praduga $t$ dak bersalah karena tersangka atau terdakwa dianggap telah terbukti bersalah kecuali ia bisa membuktikan bahwa dirinya tidak bersalah.

Menyangkut pelanggaran hak asasi manusia dalam kategori hak untuk diakui sebagai pribadi di depan hukum, dan hak untuk tidak dituntut atas hukum yang berlaku surut, walaupun peraturan tentang pelaporan harta kekayaan pejabat sudah ada, apabila penerapan asas ini tidak secara professional hal tersebut dapat timbul.

Di tunjang dengan kurangnya bukti atau kurang kuatnya bukti yang ada maka akan dapat memudahkan terdakwa lepas dari jeratan hukum. Disamping adanya kelemahan-kelemahan tersebut kurang efektifan dari sistem pembuktian terbalik ini juga di karenakan adanya kendala-kendala yang ada dalam sistem pembuktian terbalik tersebut, seringkali dimanfaatkan terdakwa untuk menyatakan bahwa ia tidak bersalah melakukan korupsi,kurangnya ahli untuk mengusut kasus korupsi, masih banyaknya jumlah hakim dan jaksa yang tidak bersih, kurangnya peran serta masyarakat.

Di Indonesia, asas praduga tidak bersalah telah diakui secara tegas di dalam Pasal 66 bahwa "Setiap orang yang disangka, ditangkap, ditahan, dituntut dan/atau dihadapkan di muka sidang pengadilan wajib dianggap tidak bersalah sampai adanya putusan pengadilan yang menyatakan kesalahannya dan memperoleh kekuatan hukum tetap".

Asas praduga tak bersalah ini juga telah diakui oleh dunia internasional Pasal 14 ayat (2) Perjanjian Internasional tenyang Hak-Hak Sipil dan Politik Tahun 1996 karena setiap orang yang dituduh melakukan pelanggaran pidana akan berhak atas praduga tak bersalah sampai terbukti bersalah menurut hukum. Sebagai komponen dasar dari hak atas suatu peradilan yang fair, asas praduga tak bersalah antara lain berarti bahwa beban pembuktian dalam suatu peradilan pidana tergantung pada penuntutan dan si tertuduh mempunyai keuntungan sebagai orang yang diragukan 18 .

Selain itu dinyatakan juga dalam Pasal 14 ayat (3) huruf g Hak-hak sipil dan Politik Tahun 1996 bahwa "dalam menentukan tuduhan pelanggaran pidana terhadapnya, setiap orang berhak untuk tidak dipaksa memberikan kesaksian terhadap diri sendiri atau mengaku bersalah". Ketentuan ini sering disebut juga dengan asas non self icrimination. Meskipun ketentuan ini tidak secara tegas mengatur tentang bukti yang didapat dengan cara pemaksaan, namun telah lama ditafsirkan bahwa bukti tersebut tidak dapat diterima di pengadilan. 
Di samping itu, dengan diamnya tersangka atau terdakwa maka tidak dapat digunakan sebaga bukti untuk menyatakan bersalah dan tidak ada kosekuensi yang negatif dapat ditarik dari pelaksanaan hak untuk diam dari seorang tersangka.

Dengan demikian, masalah pembuktian memang sangat penting dalam proses pemeriksaan suatu perkara pidana. Untuk itu penulis menganggap bahwa masalah pembuktian ini benarbenar harus dilakukan secara cermat selain itu yang harus juga diperhatikan adalah perlunya perbaikan-perbaikan dalam upaya penanggulangan korupsi. Karena korupsi mempunyai implikasi yang luas dan dapat mengganggu pembangunan serta menimbulkan kerugian negara yang sangat besar yang pada gilirannya dapat berdampat pad timbulnya krisis diberbagai bidang maka untuk upaya pencegahan dan pemberantasan perlu semakin ditingkatkan.

Pembuktian terbalik yang bersifat terbatas sebagaimana tersebut di atas, hanya terjadi di sidng pengadilan. Jika pembuktian terbalik diwajibkan pada saat berstatus sebagai tersangka, maka dikhawatirkan pembuktian terbalik itu dapat menjadi timbulnya permasalahan baru bagi penegakan hukum pemberantasan korupsi itu sendiri.

Dapat juga terjadi, pembuktian terbalik tersebut disalahgunakan oleh penyidik. Penyidik dapat melakukan penyalahgunaan wewenang dengan memeras seseorang yang telah menjadi tersangka yang diduga telah melakukan korupsi. Kekhawatiran itu selalu ada dalam wacana pembuktian terbalik sejak lama.

J.E. Sahetafy mengatakan bahwa lebih kurang tiga puluh tahun yang lalu, problematika beban pembuktian terbalik sudah menjadi wacana di dunia Fakultas Hukum: omkering van de bewijlast, begitulah probarematika pembahasan pada waktu itu. Dirasakan dan dipikirkan pada waktu itu bahwa beban pembuktian terbalik sangat tidak tepat dengan berbagai argumentasi yang tidak jauh berbeda secara substansial dengan apa yang dirasakan dewasa ini.

Masih menurut J.E. Sahetafy, pembuktian terbalik lebih layak hanya digunakan oleh hakim, dan sama sekali tidak boleh digunakan oleh penyidik. Hal itu karena pemeriksaan yang transparan hanya terdapat di persidangan pengadilan, terlepas dari praktik yang sudah tercemar dewasa ini kepolisian dan atau kejaksaan, pembuktian terbalik dalam penyidikan ini dapat menjadikan pembuktian terbalik sebagai sarana pemerasan.

Meski demikian, yang menyetujui pembuktian terbalik terhadap tersangka perkara korupsi, beranggapan bahwa jika pembuktian terbalik dilaksanakan secara benar, maka dapat lebih mempercepat atau mengoptimalkan pemberantasan korupsi. Hal itu karena, jika tersangka perkara korupsi diwajibkan membuktikan bahwa dirinya tidak bersalah, maka bukti-bukti yang diajukan tersangka dapat menjadi bahan bagi jaksa penuntut umum untuk menguatkan dakwaan di sidang Pengadilan.

Selain itu, pembuktian yang selama ini diakui, yaitu terdapat dua alat bukti yang sah ditambah keyakinan hakim, serta tersangka atau terdakwa tidak dibebani kewajiban pembuktian. Berkaitan dengan sulitnya proses pembuktian perkara korupsi, oleh karena itu perlu perlu ada dua langkah baru, salah satu nya adalah menggunakan teori "keseimbangan kemungkinan pembuktian" (balanced probability of 
principles), yaitu keseimbangan yang proposional antara perlindungan individu dan perampasan hak indivudu yang bersangkutan atas dasar bahwa harta kekeyaan diduga kuat berasal dari korupsi.

Dengan demikian, atas dasar bahwa harta kekayaan diduga kuat berasal dari korupsi , maka tersangka dapat diwajibkan untuk melakukan pembuktian bahwa ia tidak bersalah. Pembuktian terbalik sebagaimana diuraikan di atas, masih dalam lingkup hukum acara pidana.

Dalam perkara korupsi, dikenal pula pengembalian kerugian keuangan negara dengan menggunakan instrumen hukum perdata, dan hal ini telah diatur dalam UU Nomor 31 Tahun 1999 Jo UU Nomor 20 Tahun 2001. Instrumen hukum perdata ini belum operasional, karena hukum acara perdata biasa tanpa ada kekhususan. Pembuktian terbalik sebagai bagian hukum acara perdata khusus, perlu dipikirkan, agar tercapai efisiensi dan efektifitas dalam penangan perkara korupsi.

Wacana mengenai pembuktian terbalik ini juga ikut disuarakan oleh komisi hukum nasional, tajuk mengenai wacana pembuktikan terbalik ini dimunculkan melalui seminar yang bertajuk "Beban Pembuktian Terbalik dalam Penanganan Perkara Korupsi”. Permasalahan yang dibahas dalam seminar tersebut yaitu mengapa pembuktian terbalik yang diatur dalam UU Nomor 31 Tahun 1999 Jo UU Nomor 20 Tahun 2001 hanya diberlakukan terhadap tindak pidana korupsi suap menyuap saja, sementara kerugian keuangan negara yang paling banyak terjadi disebabkan oleh tindak pidana korupsi penggelapan dan pencuri kuangan negara, sebuah hal yang memang patut untuk dijadikan pembahasan tentunya.

Hal ini dikemukakan dalam diskusi publik bertema Beban Pembuktian Terbalik dalam Perkara Korupsi yang diselenggarakan Komisi Hukum Nasional di Jakarta. Pembicaraan yang hadir dalam diskusi itu adalah pakar hukum pidana Romli Atmasasmita, Direktur Perdata Kejaksaan Agung Yoseph Suardi Sabda, perwakilan dari KPK Rooseno, dan pakar hukum pidana Indriyanto Seno Adji.

UU Nomor 20 Tahun 2001 (Pasal 12 B) dan UU Nomor 15 Tahun 2002 (Pasal 37) telah memuat ketentuan mengenai sistem pembebanan pembuktian terbalik (reversal burden of proof atau onus of). Ketentuan di dalam kedua undang-undang tersebut masih belum dilandaskan kepada justifikasi teoritis sebagaimana telah diuraikan di atas, melainkan hanya menempatkan ketentuan pembebanan pembuktian terbalik tersebut semata-mata sebagai sarana untuk memudahkan proses pembuktian saja tanpa dipertimbangkan aspek hal asasi tersangka/terdakwa berdasarkan UUD 1945. Kini dengan munculnya dua model pembebanan pembuktian terbalik dengan keseimbangan kemungkinan tersebut, maka telah terdapat referensi toeritik dan praktik dalam masalah pembuktian terbalik.

Konvensi Anti Korupsi 2003 yang telah diratifikasi telah memuat ketentuan mengenai pembebanan pembuktian terbalik (Pasal 31 ayat 8) dalam konteks proses pembekuan (freezing), perampasan (seizure), dan penyitaan (confiscation). Pasca-ratifikasi Konvensi Anti Korupsi 2003 sudah tentu berdampak terhadap hukum pembuktian yang masih dilandaskan kepada UndangUndang Hukum Acara Pidana Nomor 8 
Tahun 1981 dan ketentuan mengenai penyelidikan, penyidikan dan penuntutan serta pemeriksaaan pengadilan di dalam UU Nomor 31 Tahun 1999.

Yang terpenting dalam hukum pembuktian kasus korupsi, sudah seharusnya unsur kerugian negara yang nyata bahkan yang masih diperkirakan akan nyata kerugiannya, sudah tidak pada tempatnya dan tidak proposional lagi untuk dijadikan unsur pokok dalam suatu tindak pidana korupsi, dan kerena nya tidak perlu harus dibuktikan lagi. Bahkan kerugian masyarakat luas terutama pihak ketiga yang dirugikan karena korupsi sudah seharusnya diakomadasi di dalam UU baru pemberantasan korupsi.

Korupsi yang telah disadari sebagia extra ordinary crime yang berdampak secara multiplier terhadap seluruh sendi kehidupan masyarakat, menuntut penindakan yang extra ordinary juga. Olehnya, kehadiran Pembuktian Terbalik secara mutlak (penuh) dalam sistem pembebanan pembuktian menjadi sesuatu yang sangat dibutuhkan dalam upaya pemberantasan korupsi.

Pemberantasan korupsi harus dengan legelitas, artinya hukum formil satu0satunya ukuran yang dapat dikenakan pada seseorang yang diduga melakukan tindak pidana korupsi, alasannya adalah suatu kebenaran bahwa asas mullum delictum sine praevia lege poenali ditunjuan untuk menjamin kepastian hukum, dan didalam kepastian hukum tersebut dengan sendirinya terkandung rasa keadilan masyarakat.

\section{DAFTAR PUSTAKA}

\section{A. Buku-buku :}

Jimly Asshiddiqi, Konstitusi dan Konstitusionalisme Indonesia, Jakarta, 2004
J.Kaloh, Mencari Bentuk Otonomi Daerah, Suatu Solusi Dalam Menjawab Kebutuhan lokal Dari Tantangan Global, Renika Cipta, Jakarta, 2002

Miriam Budiardjo, Dasar-dasar ilmu politik, gramedia pustaka utama, Jakarta, 1998

MiftahToha, Manajemen Kepegawaian Sipil di Indonesia. Kencana Prenada Media Group, Jakarta, 2008

Muhammad Kusnardi dan Harmaily Ibrahim, Pengantar Hukum Tata Negara Indonesia,(PSHTN FH UI) dan Sinar Bakti, Jakarta, 1988

Moh. Mahfud MD, Hukum Kepegawaian Indonesia, Liberty Yogyakarta 1988

Philipus M Hadjon, Etal, Pengantar Hukum Administrasi Indonesia, Gadjah Mada University, Yogyakarta, 2005

Satjipto Rahardjo, Ilmu Hukum, PT. Citra aditya Bakti, Bandung 2000

Sedarmayanti, Sumber Daya Manusia dan Produktivitas Kerja, Mandar Maju, Bandung, 2001

Soerjono Soekanto, Metode Penelitian Hukum, Rineke Cipta, Jakarta

B. Peraturan Perundang-Undangan :

Undang-Undang Nomor 08 Tahun 1974 Tentang Pokok-pokok Kepegawaian

Undang-Undang Nomor 43 Tahun

1999 Tentang Pokok-pokok Kepegawaian

Peraturan Pemerintah Nomor 100 Tahun 2000 Tentang Pengangkatan Pegawai Negeri Sipil Dalam Jabatan Struktural

Peraturan Pemerintah Nomor 13 Tahun 2002, Tentang Perubahan Atas Peraturan Pemerintah Nomor 100 Tahun 2000 Tentang Pengangkatan Pegawai Negeri Sipil Dalam Jabatan Struktural. 